SPECIAL

- COMMUNICATION-

Volume 12 Issue 32020

DOI: 10.21315/eimj2020.12.3.3

ARTICLE INFO

Submitted: $16-01-2020$

Accepted: 13-02-2020

Online: 30-09-2020

\section{Professionalism through Entrustable Professional Activities: ABC of This Imperative and Inevitable Approach}

\author{
Kamran Sattar, Muhamad Saiful Bahri Yusoff \\ Department of Medical Education, School of Medical Sciences, \\ Universiti Sains Malaysia, Kelantan, MALAYSIA
}

To cite this article: Sattar K, Yusoff MSB. Professionalism through entrustable professional activities: ABC of this imperative and inevitable approach. Education in Medicine Journal. 2020;12(3):21-29. https://doi.org/10.21315/eimj2020.12.3.3

To link to this article: https://doi.org/10.21315/eimj2020.12.3.3

\begin{abstract}
Medical schools worldwide strive to produce future doctors, who are fit to practice, in other words, doctors who are equipped with professionalism attributes. The same is the demand from almost every walk of any society. "Assessment drives learning", therefore, a valid and reliable assessment of core professionalism attributes of undergraduate medical students is vital to ensuring the overall satisfactory achievement of behaviours which best serve the society. In the recent past, the concept of entrustable professional activities (EPAs), as a method of assessment in competency-based education has begun to gain considerable significance and attention from medical educators, all over the world. Based on recent literature, this article offers ABC (Attributes of EPAs, Baseline EPAs, and Core Professionalism) elements for this new approach as well as practical and useful recommendations on how to integrate EPAs for assessment of professionalism of undergraduate medical students.
\end{abstract}

Keywords: Professionalism, Assessment, EPAs, Innovative, Inevitable, Approach, Undergraduate, Medical, Student

Dr. Kamran Sattar, Department of Medical Education, School of Medical Sciences, Universiti Sains Malaysia, 16150 Kubang Kerian, Kelantan, Malaysia | Email: drkamransattar@student.usm.my

\section{INTRODUCTION}

As the name suggests, entrustable professional activities (EPAs) are based on the concept of trust. They answer the question, "What can a medical graduate, or medical resident actually be entrusted to do?" Moreover, competencies describe the qualities of providers, EPAs describe the work that is to be done and they are designed to ground the competencies in the everyday work of the provider. The concept of entrustment has almost always existed in the apprenticeship model of medical education, but EPAs bring a new level of standardisation and structure to the assessment of activities that are entrusted during the progression of training. Therefore, once the learners have gained sufficient competence, they compulsorily require to show explicit knowledge, skills and behaviours of such training without direct supervision. Operationalisation of EPAs at the undergraduate level is relatively new. Whereas, in 2005, the four professional physician assistant 
organisations; the American Academy of Physician Assistants (1), the Accreditation Review Commission on Education for the Physician Assistant (2), the National Commission on Certification of Physician Assistants (3), and the Physician Assistant Education Association (4) adopted the Accreditation Council for Graduate Medical Education's (ACGME) six competency domains (Table 1), as the basis for professional competencies (5). These physicians assistants competencies were revised in 2012, and it seems likely that on their next revision they will incorporate the two additional domains, "interprofessional" and "personal professional development," that ACGME added to the most recent iteration of its competency domains. Consequently, the clinicians get help from EPAs, about their everyday decision whether to trust a student for performing a precise task (6).

Table 1: ACGME competencies with an explanation of professionalism commitments expected of young physicians

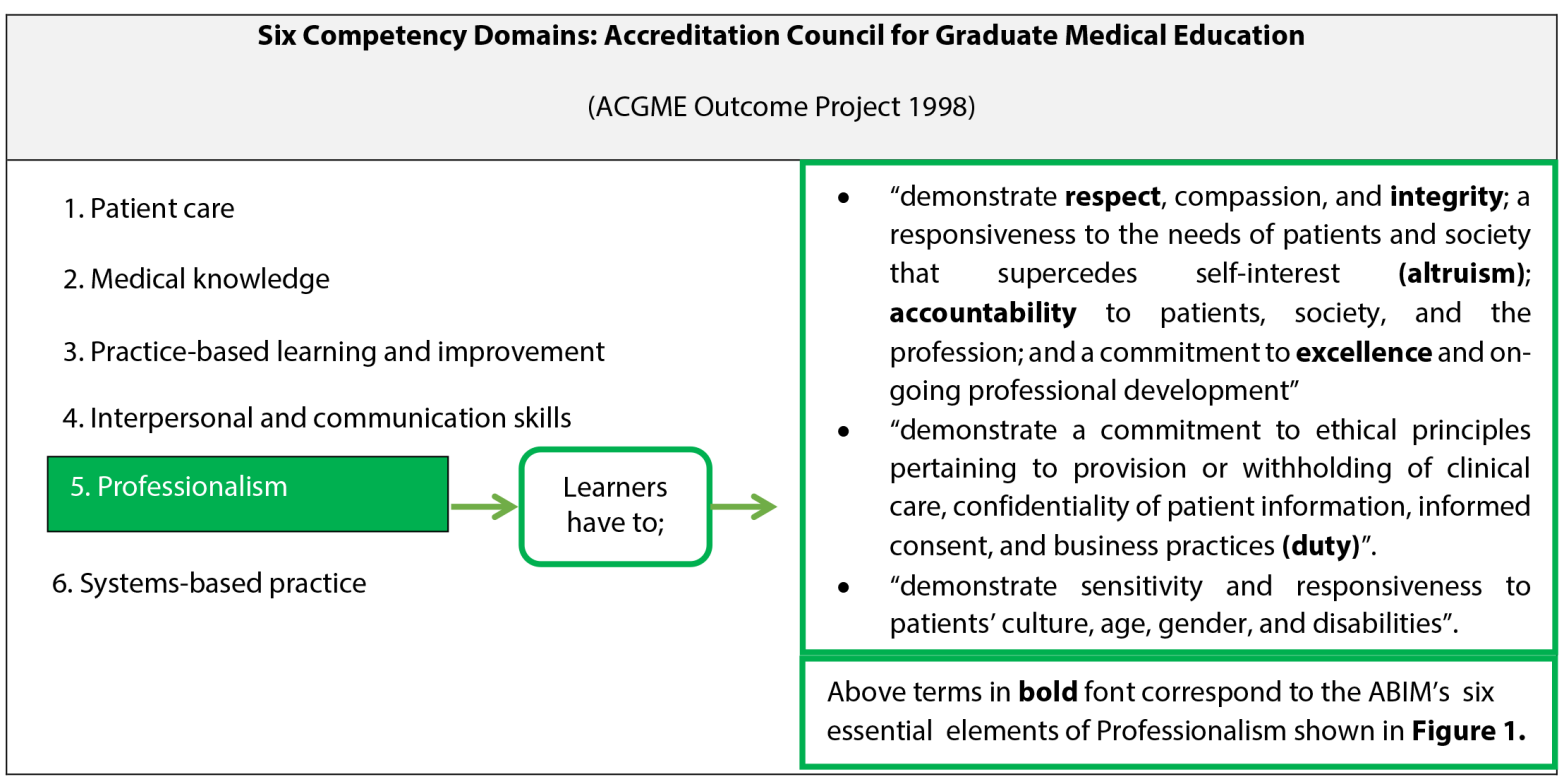

\section{Attributes of EPAs}

In the early 2000s, ten Cate and Scheele at the University of Utrecht began considering to have a link between theory and practice in medical education (7). It was also observed that wide-ranging domains of professionalism are, however, substantial, and medical education should develop and assess both the student's aptitude to perform essential tasks and to cultivate the general attributes of a "good doctor" (7).

It is believed that, in its maiden times, the EPAs were targeted and formulated for residents, fellows, physician and assistants, yet, in recent times, started to be considered for medical students. This was to address some of the prevailing concerns, e.g., the gap between the performance of new residents and the expectations of residency programme directors (8), this is where medicine has begun to embrace the concept of "entrustable professional activities". Thus, it is considered that medical students were encouraged and stimulated to perform excellently in their practice of medicine.

\section{Baseline EPAs}

American and Canadian medical educators approved a set of 13 "core EPAs" (Figure 1) and agreed that medical students needs to be assigned to do, while graduated from medical school having a supervisor close enough to help, when needed (8). 
These tasks are known and labeled as "core EPAs". Considering it to be the need of the hour, in May 2014, Association of American Medical Colleges, published a curriculum developer's guide with emphasis on EPAs, listed as core entrustable professional accomplishments for entering residency (9).

\section{Core Professionalism and Its Behavioural Context}

Although in June 2016, there were 5,898 manuscripts identified, while searching the PubMed and these all were about medical professionalism, yet, the definition of professionalism is still unclear (10). However, globally, all stakeholders of healthcare agree on the ever-expanding and ever-changing significance of professionalism. Medical schools worldwide strive to produce future doctors who are fit to practice and equipped with professionalism behaviours. Therefore, medical professionalism is rightly considered as an essential aspect of medical education and practice worldwide (11). Whenever, and wherever doctors are to be assessed and evaluated, the professionalism stands as an central criteria (12-16). The Malaysian Medical Council also outlines professionalism, having a set of behaviours expected of a medical professional (17).

Widespread literature places professionalism as central to the practice of medicine, yet, at the same time, it is considered that its assessment, is almost as challenging as the value we place on it. Moreover, its valuation is disadvantaged by variable definitions which fell short of a clear itemisation of the essentials of professionalism into measurable features. Understanding of professionalism differs across time and cultural contexts (18), signifying that professionalism is a multifaceted, multi-dimensional concept (19). Over the last three decades, numerous tools were practiced in many empirical researches $(20,21)$ and still, it was believed, that the assessment of fairly indefinite and very general concepts as "professionalism" is challenging. Therefore, we shall now start looking to have an assessment recipe that can reliably and validly assess its all constructs.

Quantifying the virtues have always been extremely challenging whereas, the behaviours are observable as well as measurable. Indeed, "professional duties" and "milestones" were identified that are to be evaluated (22). Furthermore, professional responsibilities are considered central by Physician Charter (12). The Canadian Medical Association also highlighted such responsibilities, towards the patient, society, profession, and to oneself, arguing that this results in guiding professionalism through physician behaviour (23).

\section{Professionalism Behaviours through EPAs}

The American Board of Internal Medicine (ABIM) Monograph on professionalism classifies six fundamentals of professionalism (i.e., altruism, accountability, excellence, duty, honour and integrity, and respect for others). The Pennsylvania State University College of Medicine (PSCOM) Task Force carried out affective item development (24) and succeeding in establishing 60 items. These items represent the frequently growing explanations of professionalism which were accepted and recognised as founded on the six ABIM elements. This common list of items also remained stable with its wide popularity as later attracted another internal document, addressing the objectives of the undergraduate medical education at PSCOM. Using the modified Delphi technique (25), more discussion occurred, letting the task force take 41 items, out of initial 60 items. Furthermore, as a result of the final categorisation and coding of each item, six statements were agreed upon for each element and the final instrument confined 36 items, with full consensus. At the end, these 36 items were present in each form signifying the six professionalism essential elements by ABIM: accountability, altruism, duty, excellence, honesty and integrity, and respect. 


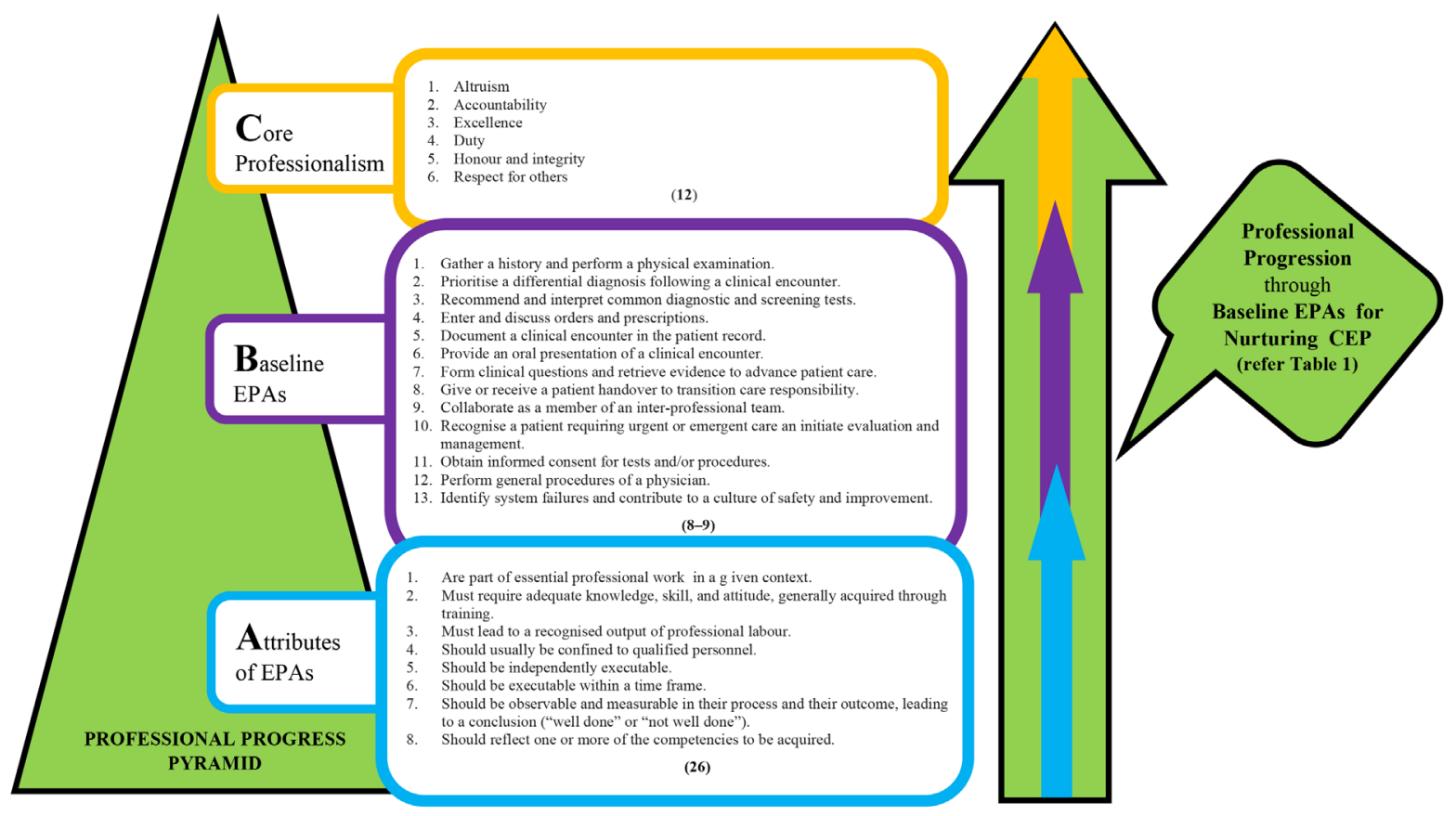

Figure 1: Professional progress pyramid.

\section{PRACTICE RECOMMENDATIONS}

The importance of aligning and assimilating professionalism within core EPAs is identified (Table 2). Medical educationists are encouraged to embrace through the stated potential and practical ways to integrate interpersonal and communication skills within professionalism and as a step ahead, professionalism competencies further need to be incorporated into the Core EPAs for Entering Residency (9). The EPAs assessments are based on specific, observable activities which practically and naturally fit into professionalism elements assessment frameworks. Furthermore, EPAs can also be used to drive curriculum development within undergraduate syllabus where the pre-clinical students shall be inculcated with the cognitive part of professionalism. This later shall be embedded within the practical and psychomotor part of EPAs (e.g., with the help of simulated patients) within the clinical years. This shall, in later years, i.e., clinical year may gradually be replaced with more of practical endorsements of blended professionalism within a more robust EPAs (clinical encounters with real patients). Medical school programme directors should use EPAs (because of literature evidence shown in above texts), as they are envisioned to reinforce professionalism elements, and improve professional standards of the learners. It is believed that if EPAs are implemented in a blended framework, with professionalism, there shall not remain any gaps, between "learner supervised assessment" of competence and their future "real-life practice". 
Table 2: Description, medical education context and literature significance of core elements of professionalism (CEP), with examples of baseline EPAs to nurture them

\begin{tabular}{|c|c|c|c|c|}
\hline 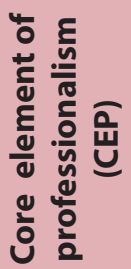 & $\begin{array}{l}\text { Description of the CEP } \\
\text { (Merriam-Webster) }\end{array}$ & $\begin{array}{l}\text { Medical education context } \\
\text { of the CEP }\end{array}$ & $\begin{array}{c}\text { Existing literature evidence about the } \\
\text { significance } \\
\text { of the CEP }\end{array}$ & $\begin{array}{l}\text { *13 Baseline EPAs for nurturing CEP } \\
\text { (Students are expected to:) }\end{array}$ \\
\hline 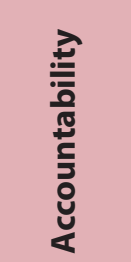 & $\begin{array}{l}\text { Readiness to accept } \\
\text { responsibility or to account } \\
\text { for one's actions. }\end{array}$ & $\begin{array}{l}\text { Accommodating } \\
\text { responsibility and avoiding } \\
\text { the business of blaming } \\
\text { colleagues. }\end{array}$ & $\begin{array}{l}\text { Accountable members are present in } \\
\text { excellent organisations. } \\
(27,28) \text {. } \\
\text { Communities are empowered due to } \\
\text { doctors' accountability }(29) \text {. }\end{array}$ & $\begin{array}{l}\text { 5. "Document a clinical encounter in } \\
\text { the patient record". } \\
\text { 8. "Give or receive a patient handover } \\
\text { to transition care responsibility". }\end{array}$ \\
\hline$\frac{\varepsilon}{\frac{\varepsilon}{2}}$ & $\begin{array}{l}\text { Unselfish regard for or } \\
\text { devotion to the welfare of } \\
\text { others. }\end{array}$ & $\begin{array}{l}\text { Putting the duty and } \\
\text { patient care ahead of your } \\
\text { own needs. }\end{array}$ & $\begin{array}{l}\text { Physicians select to be altruistic ( } 30) \text {. } \\
\text { Differences exist between the altruism of } \\
\text { patients and physicians ( } 31) \text {. }\end{array}$ & $\begin{array}{l}\text { 10. "Recognise a patient requiring } \\
\text { urgent or emergent care and initiate } \\
\text { evaluation and management". }\end{array}$ \\
\hline ثे & $\begin{array}{l}\text { Tasks, conduct, service, or } \\
\text { functions that arise from } \\
\text { one's position. }\end{array}$ & $\begin{array}{l}\text { Balancing the interests and } \\
\text { wishes of the patient with } \\
\text { the welfare of the health } \\
\text { care system. }\end{array}$ & $\begin{array}{l}\text { It is the duty of the physicians to deliver } \\
\text { care to the patients (25). }\end{array}$ & $\begin{array}{l}\text { 1. "Gather a history and perform a } \\
\text { physical examination". } \\
\text { 4. "Enter and discuss orders and } \\
\text { prescriptions". } \\
\text { 9. "Collaborate as a member of an } \\
\text { inter-professional team". } \\
\text { 12. "Perform general procedures of a } \\
\text { physician". }\end{array}$ \\
\hline
\end{tabular}




\begin{tabular}{|c|c|c|c|c|}
\hline 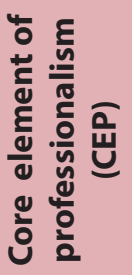 & $\begin{array}{l}\text { Description of the CEP } \\
\text { (Merriam-Webster) }\end{array}$ & $\begin{array}{l}\text { Medical education context } \\
\text { of the CEP }\end{array}$ & $\begin{array}{c}\text { Existing literature evidence about the } \\
\text { significance } \\
\text { of the CEP }\end{array}$ & $\begin{array}{l}\text { *13 Baseline EPAs for nurturing CEP } \\
\text { (Students are expected to:) }\end{array}$ \\
\hline 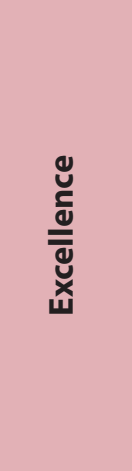 & $\begin{array}{l}\text { An excellent or valuable } \\
\text { quality. }\end{array}$ & $\begin{array}{l}\text { Exhibiting medical skill } \\
\text { that is unusually good } \\
\text { and surpasses ordinary } \\
\text { standards. }\end{array}$ & $\begin{array}{l}\text { An excellent doctor is always available with } \\
\text { his full attention towards the community he } \\
\text { serves (32). }\end{array}$ & $\begin{array}{l}\text { 7. "Form clinical questions and retrieve } \\
\text { evidence to advance patient care". } \\
\text { 10. "Recognise a patient requiring } \\
\text { urgent or emergent care an initiate } \\
\text { evaluation and management". } \\
\text { 3. "Recommend and interpret common } \\
\text { diagnostic and screening tests". } \\
\text { 6. "Provide an oral presentation of a } \\
\text { clinical encounter". } \\
\text { 2. "Prioritise a differential diagnosis } \\
\text { following a clinical encounter". }\end{array}$ \\
\hline 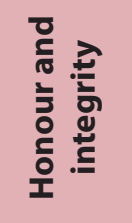 & $\begin{array}{l}\text { Honour - good name or } \\
\text { public esteem. } \\
\text { Integrity - Highest standards } \\
\text { of behaviour (being fair, } \\
\text { honest and truthful). }\end{array}$ & $\begin{array}{l}\text { Exhibiting the highest } \\
\text { standards of behaviour. }\end{array}$ & $\begin{array}{l}\text { Physicians are expected to exhibit honour } \\
\text { and integrity (33). }\end{array}$ & $\begin{array}{l}\text { 11. "Obtain informed consent for tests } \\
\text { and/or procedures". }\end{array}$ \\
\hline $\begin{array}{l}\longleftarrow \\
\check{o} \\
\frac{o}{y} \\
\simeq\end{array}$ & $\begin{array}{l}\text { An act of giving particular } \\
\text { attention. }\end{array}$ & $\begin{array}{l}\text { Avoiding offensive } \\
\text { speech that offers unkind } \\
\text { comments and unfair } \\
\text { criticisms to patients and } \\
\text { colleagues. }\end{array}$ & $\begin{array}{l}\text { Respect shall be demonstrated towards his/ } \\
\text { her patients, colleagues, for the profession } \\
\text { of medicine, as well as for him/herself (34). }\end{array}$ & $\begin{array}{l}\text { 10. "Recognise a patient requiring } \\
\text { urgent or emergent care an initiate } \\
\text { evaluation and management". } \\
\text { 13. "Identify system failures and } \\
\text { contribute to a culture of safety and } \\
\text { improvement". }\end{array}$ \\
\hline
\end{tabular}

Note: *Derived from the list of core and baseline EPAs (some may be repeated while addressing multiple elements of professionalism in Figure 1: Professionalism progress pyramid). 


\section{CONCLUSION}

As medical educators, we always struggle to exercise practical and useful ways to motivate and encourage our students to reach for distinctions while practicing medicine. Hence, applying the recommendations stated in this article can help us to do just this. Moreover, this shall let medical educators discover in detail about the future prospects of EPAs as a framework of learning outcomes through labeling as what our medical students shall ideally demonstrate before they move out from their medical schools into to real life practice.

\section{REFERENCES}

1. American Academy of PAs. AAPA governance \& leadership. Available from: https:/www.aapa.org/about/ [cited August 2018].

2. Accreditation Review Commission on Education for the Physician Assistant (ARC-PA). Physician assistant history society. Available from: https://pahx.org/ nomenclature/arc-pa/ [cited February 2019].

3. National Commission on Certification of Physician Assistants. PA Programs. Available from: https://www.nccpa.net/ [cited September 2018].

4. Physician Assistant Education Association. PAEA Learning. Available from: https:// paeaonline.org/ [cited March 2019].

5. Stanford Medicine. Graduate Medical Education. Available from: http://med. stanford.edu/gme/housestaff/all-topics/core_ competencies.html [cited February 2019].

6. ten Cate O. Nuts and bolts of entrustable professional activities. J Grad Med Educ. 2013;5(1):157-8. https://doi.org/10.4300/ JGME-D-12-00380.1
7. ten Cate O, Scheele F. Viewpoint: competency-based postgraduate training: can we bridge the gap between theory and clinical practice? Acad Med. 2007;82(6):542-7. https://doi.org/10.1097/ ACM.0b013e31805559c7

8. Englander R, Flynn T, Call S, Carraccio C, Cleary L, Fulton TB, et al. Toward defining the foundation of the MD degree: core entrustable professional activities for entering residency. Acad Med. 2016;91(10):1352-8. https://doi. org/10.1097/ACM.0000000000001204

9. Association of American Medical Colleges (AAMC). Core entrustable professional activities for entering residency: curriculum developers' guide. Washington, D.C.: AAMC iCollaborative; 2014. Available from: https://www.mededportal.org/icollaborative/ resource/887 [cited 23 October 2019].

10. Yang $H$. Professionalism in anesthesia. Can J Anesth. 2017;64:149-57. https://doi. org/10.1007/s12630-016-0738-3

11. Sattar K, Roff S, Siddiqui D, Meo SA. Standing out with professionalism: how do students and faculty of two different medical schools perceive it? Pak J Med Sci. 2017;33(5):1248. https://doi.org/10.12669/ pjms.335.13432.

12. ABIM Foundation, American Board of Internal Medicine, ACPASIM Foundation, American College of Physicians-American Society of Internal Medicine, European Federation of Internal Medicine. Medical professionalism in the new millennium: a physician charter. Ann Intern Med. 2002;136:243-6. https://doi. org/10.7326/0003-4819-136-3-20020205000012

13. Irvine D. Patients, professionalism and revalidation. $\mathrm{Br}$ Med J. 2005;330(7502):1265-8. https://doi. org/10.1136/bmj.330.7502.1265 
14. General Medical Council (GMC). Tomorrow's doctors (GMC/TD/)914. Manchester: General Medical Council; 2009. p. 1-100.

15. Scottish Government. Professionalism in nursing, midwifery and allied health professions in Scotland: a report to the coordinating council for the NMAHP contribution to the healthcare quality strategy for NHS Scotland. Edinburgh: Crown, The Scottish Government; 2012. p. 3-38.

16. Health Care and Professions Council (HCPC). Professionalism in healthcare professionals. London: HCPC; 2014. p. 3-64.

17. Code of Professional Conduct. Malaysian Medical Council. December 1986. Available from: http://mmc.moh.gov.my/images/ contents/ethics/CURRENT_CPC_TILL_ APRIL_2020.pdf [cited March 2019].

18. Hodges BD, Ginsburg S, Cruess R, Cruess S, Delport R, Hafferty F, et al. Assessment of professionalism: recommendations from the Ottawa 2010 Conference. Med Teach. 2011;33(5):354- 63. https://doi.org/10.3109 /0142159X.2011.577300

19. Wilkinson TJ, Wade WB, Knock LD. A blueprint to assess professionalism: results of a systematic review. Acad Med. 2009;84(5):551-8. https://doi.org/10.1097/ ACM.0b013e31819fbaa2

20. Veloski JJ, Fields SK, Boex JR, Blank LL. Measuring professionalism: a review of studies with instruments reported in the literature between 1982 and 2002. Acad Med. 2005;80(4):366-70. https://doi. org/10.1097/00001888-200504000-00014

21. Lynch DC, Surdyk PM, Eiser AR. Assessing professionalism: a review of the literature. Med Teach. 2004;26:366-73. https://doi.org /10.1080/01421590410001696434
22. CanMEDS 2015. The CanMEDS 2015 Framework. Available from: http://canmeds. royalcollege.ca/en/framework [cited June 2016].

23. Canadian Medical Association. CMA Code of Ethics 2004 [updated March 2015]. Available from: https://www.cma.ca/Assets/ assets-library/document/en/advocacy/policyresearch/CMA_Policy_Code_of_ethics_ of_the_Canadian_Medical_Association_ Update_2004_PD04-06-e.pdf [cited June 2016].

24. Gable RK, Wolf MB. Instrument development in the affective domain: measuring attitudes and values in corporate and school settings. Netherlands: Springer; 1993. pp. 217. https://doi.org/10.1007/97894-011-1400-4

25. Picard EI, Robertson GB. Legal liability of physicians and hospitals in Canada. 4th ed. Toronto (ON): Thomson Carswell; 2007.

26. ten Cate O. Entrustability of professional activities and competency-based training. Med Educ. 2005;39(12):1176-7. https://doi. org/10.1111/j.1365-2929.2005.02341.x

27. Lencioni P. The five dysfunctions of a team. San Francisco, CA: Jossey-Bass; 2002.

28. Katzenbatch JR, Smith DK. The wisdom of teams. Boston, MA: Harvard Business School Press; 1993.

29. Green-Thompson LP, McInerney P, Woollard B. The social accountability of doctors: a relationship based framework for understanding emergent community concepts of caring. BMC Health Serv Res. 2017;17:269. https://doi.org/10.1186/ s12913-017-2239-7.

30. Hennig-Schmidt H, Selten R, Wiesen D. How payment systems affect physicians' provision behavior - an experimental investigation. Journal of Health Economics. 2011;30:637-46. https://doi.org/10.1016/j. jhealeco.2011.05.001 
31. Brosig-Koch J, Hennig-Schmidt H, KairiesSchwarz N, Wiesen D. The effects of introducing mixed payment systems for physicians: experimental evidence. Health Economics. 2017;26: 243-62. https:/doi. org/10.1002/hec.3292

32. Carvalho D. A prescription for physician excellence. Braz J Otorhinolaryngol. 2016;82:491-2. https://doi.org/10.1016/j. bjorl.2016.06.003
33. Kanter $\mathrm{MH}$, Nguyen $M$, Klau $M H$, Spiegel NH, Ambrosini VL. What does professionalism mean to the physician? Perm J. 2013;17(3):87-90. https://doi. org/10.7812/TPP/12-120

34. Wong JG. R-E-S-P-E-C-T-Implications for physicians and physicians-to-be. J Gen Intern Med. 2014;29:1096. https://doi. org/10.1007/s11606-014-2871-4 